\title{
Work-Life Balance, Couple Satisfaction, and Father Involvement: A Cross-Cultural Study
}

\author{
Gaby Ersinta Parung \\ School of Health in Social Science \\ University of Edinburgh \& \\ Deimago Educare International
}

\author{
Nuno Ferreira \\ School of Health in Social Science \\ University of Edinburgh
}

The goals of the study were to identify: (a) the differences in father involvement level between
fathers in the United Kingdom and Asia; (b) the differences in father involvement between
fathers within Asia (Indonesia and Hong Kong); and (c) the factor that contributed to father
involvement the most: work-life balance or couple satisfaction. By using snowball sampling,
256 fathers ( 51 from the United Kingdom, 106 from Indonesia, and 99 from Hong Kong) par-
ticipated in the study via an online survey that measured their level of involvement, couple sa-
tisfaction, and work-life balance. Results revealed a statistically significant difference in father
involvement between fathers from Indonesia and Hong Kong $(t=6.307, p<.000,95 \%=$
$16.286,31.101)$, but not between fathers from the United Kingdom and Asia $(t=-.487, p=$
$.627,95 \%=-8.003,-4.841$ ). Couple satisfaction was directly correlated to father involvement
and also acted as the mediating factor between work-life balance and father involvement mean-
ing that father involvement was influenced by a larger system that was interconnected with
wider society as well as the couple relationship.

Keywords: work-life balance, couple satisfaction, father involvement, cross-cultural study

Tujuan studi ini adalah untuk mengidentifikasi: (a) perbedaan tingkat keterlibatan ayah di Inggris Raya dalam pengasuhan dibandingkan ayah di Asia; (b) perbedaan tingkat keterlibatan ayah dalam pengasuhan di wilayah Asia (Indonesia dan Hong Kong); dan (c) faktor yang berkontribusi paling besar pada keterlibatan ayah dalam pengasuhan, kepuasan perkawinan, atau work-life balance. Dengan menggunakan snowball sampling, 256 ayah (51 dari Inggris Raya, 106 dari Indonesia, dan 99 dari Hong Kong) berpartisipasi dalam studi ini dengan mengisi format daring yang mengukur tingkat keterlibatan ayah dalam pengasuhan, kepuasan perkawinan, dan work-life balance. Hasil menunjukkan perbedaan signifikan dalam keterlibatan ayah dalam pengasuhan di antara ayah di Indonesia dan Hong Kong $(t=6.307, p<.000,95 \%=$ 16.286, 31.101), tapi tidak antara ayah di Inggris Raya dan Asia $(t=-.487, p=.627,95 \%=$ - 8.003, - 4.841). Kepuasan pasangan berkorelasi langsung dengan keterlibatan ayah dalam pengasuhan, dan juga berperan sebagai faktor yang memediasi work-life balance dan keterlibatan ayah. Hal ini menunjukkan keterlibatan ayah dalam pengasuhan dipengaruhi oleh sistem sosial yang lebih besar dan saling terhubung, dan juga kualitas hubungan pasangan.

Kata kunci: work-life balance, kepuasan pasangan, keterlibatan ayah, studi lintas budaya

Parenting practises have shifted considerably over the last few decades. In traditional methods of parenting, mothers were solely responsible for care giving, providing a secure base for the children, and the domestic tasks; meanwhile, fathers were seen as the exploration partners for the children who engaged in physical play and encouraged risk taking (Newland \& Coyl, 2010; Newland et al., 2012). Nowadays, fa-

Correspondence concerning this article should be addressed to Gaby Ersinta Parung. Jalan Boulevard Komp. Lily Blok C19, Makassar. Email: gabyersinta@hotmail.com thers are viewed as active participants in children's lives and development. The increasing need for a dual income in the family also encouraged mothers to work. As a result, the household and parenting dynamics are changing to an equal role of parenting and working between both father and mother (Machin, 2015; Mehall, Spinrad, Eisenberg, \& Gaertner, 2009). The role of father and mother are more blended and this has resulted in a higher level of involvement in parenting and caring for the child (Haywood \& Mac an Ghail, 2002). The father's involvement in the fa- 
mily "has evolved from the moral teacher or guide, the breadwinner, the sex role model, finally becoming the new nurturant father" (Lamb, 2000). The quantity of time provided by fathers to the child has also increased to almost eightfold the time given before (Crompton \& Lyonette, 2008; Gray, 2006; O’Brien, 2005). It is also considered to be a normative norm for fathers to be involved in the childcare in the United Kingdom nowadays (Dermott, 2008).

Although the recognition of father involvement is considerably high in the West, Eastern society has not put much importance in this concept. The level of paternal involvement in Asia is still relatively lower than the maternal (Juhari, Yaacob, \& Talib, 2013). Mothers in Asia are still expected to take care of children and engage in domestic works. In Malaysia and India, fathers only spend a short amount of time with their children because fathers are not expected to help with parenting tasks (Hossain et al., 2005; Suppal \& Roopnarine, 1999). In a small survey conducted by an Indonesian parenting magazine, Ayah Bunda (Elia, 2000), $61 \%$ of fathers stated they should be the only breadwinner, $62 \%$ fathers stated they will only contribute in parenting if extremely necessary, and $33 \%$ stated that they do not need to spend time with their children every day.

With a strong collective culture in Asia, women in nuclear and extended families are expected to help the new mother; hence, some fathers do not feel the need to be involved in child-rearing. Nevertheless, new fathers with higher education levels in Asia are starting to become more involved in taking care of the children despite the previous parenting tradition (Yeung, 2010). Media coverage for paternal involvement is also growing in Asia, such as The Community of Edy's Father and Fathers Exist in Indonesia, Singapore Dad for Life Movement in Singapore, Dads Network and Hong Kong Dads in Hong Kong, and the Super Dad Campaign in India. These platforms help fathers acquire information about parenting (in books, blogs, and from social media) and can also act as group help because members can post their problems and the rest can help with their experiences with similar problems. The support group can theoretically increase fathers' participation in child rearing activities (Lamb, Pleck, \& Levine, 2010) which may help increase the level of fathers' involvement in Asia.

\section{Father Involvement}

Father involvement is a multidimensional con- struct that incorporates affective, cognitive, ethical, and observable behaviour as well as indirect involvement components (Hawkins \& Palkovitz, 1999). It has been described as having three dimensions: intensity (the quantity of time spent with children), nature (the type of activities fathers engaged in with the children), and quality (the appreciation of fathers' own involvement) (Turcotte, Dubeau, Bolte', \& Paquette, 2001). Furthermore, as described by Lamb, Pleck, Charnov, and Levine (1987), there are three types of paternal involvement which are paternal engagement, accessibility, and responsibility. The fulfilment of the three is linked to positive effects on both fathers and children. Fathers involved in parenting report having a higher sense of self-worth (Lewis \& Lamb, 2007), a higher level of confidence in parenting (Baruch \& Barnett, 1986; Keizer, 2015; McLaughlin \& Muldoon, 2014), as well as a better sense of psychological (Kwok, Ling, Leung, \& Li, 2013) and physical well-being (Janzen \& Kelly, 2012).

Meanwhile, for children whose fathers are involved, they are most likely to have better cognitive development and educational achievement (Flouri, 2005; Kaplan, 1996; Lamb, 2004), better social competence (Aldous \& Mulligan, 2002; Lamb, 2004), a lower chance of later delinquency (Flouri \& Buchanan, 2002), and improved physical (Janzen \& Kelly, 2012) and mental health (Flouri, 2005; Lamb, 2004).

With the recognition of the advantages of being involved in the family, new fathers have started to spend more time in caring for their children to develop and increase long-term father-child bonds between them (Moss \& Deven, 1999). A qualitative research study by McLaughlin and Muldoon (2014) shows that new fathers perceive fatherhood as a beneficial role for themselves instead of a constraint or problematic role. The more they are involved in the parenting, the more confident they are and the more likely they are to experience enjoyment from the process. One of the subjects also noted a positive change (receiving more respect and independence) in his work environment when he became a father.

Although many studies have proven positive benefits of father involvement, fathers in Asia still have less involvement in parenting. Fathers in Asia, especially in Chinese culture, are seen as the leader of the family with absolute power and children are expected to be obedient and respectful to them (Hsu, 1985; Kwok \& Li, 2014). In Malay culture, good fatherhood is defined by fathers being strict and enforcing discipline upon the children. However, this practice resulted in a poor relationship between fathers and 
children, especially sons (Siraj, 2007). With the increasing of female workers and education levels, the trend of parenting has shifted toward an equalitarian attitude (Kwok \& Li, 2014). However, with the small number of research in father involvement in Asia, it is quite difficult to determine Asian stances on the involvement in general. Moreover, most of the studies are largely focused on Chinese culture and a very small amount study other cultures. Hence, more research is needed to provide a broader and more objective understanding of father involvement in Asia.

\section{Work-Life Balance}

Work-life balance is a concept of global assessment that one's family and work resources are adequate in fulfilling both demands effectively (Voydanoff, 2005). It has three dimensions: work interference with personal life, personal life interference with work, work/personal life enhancement (Fisher-McAuley et al., 2003; Hayman, 2005). With these concepts, a work-life balance had been developed previously for mothers to help overcome the constraints of the need to work and parent by creating regulations in regard to providing part-time jobs or at least flexible work hours, child care facilities in the company, or parental leave (Fagnani \& Letablier, 2004; Gregory $\&$ Milner, 2010). Nonetheless, with the expectation for fathers to become more involved in familial life, new fathers are experiencing more work-life conflict than mothers (Aumann, Galinsky, \& Matos, 2011).

Government policy also tends to side with mothers. For example, the United Kingdom paternity leave duration is two weeks compared with 39 weeks of maternity leave. However, from the 5th April 2015, both parents can share a maximum of 52 weeks of parental leave together (Maternity Pay and Leave, 2016; Paternity Pay and Leave, 2016). Though the policy has been changed to help new parents, most fathers do not have enough economic security to take that leave as they will only receive a maximum GBP 139.50 per week (Shared Parental Leave and Pay, 2016). This figure is not enough to provide for mortgages and the increased basic needs due to the new addition in the family (Machin, 2015). Hence, those who are able to take and commit to a longer term of paternity leave are usually the fathers with higher socioeconomic status and higher paying jobs (Nepomnyaschy \& Waldfogel, 2015). Other than that, the cultural norms regarding fathers and masculinity, the limited support and benefits from work, the incompatibility of fathers' ideal self, and the lack of socialisation and information about the leave can also become the hindrances to fathers in achieving work and life balance (Halford, 2006; McLaughlin \& Muldoon, 2014).

The policy in Europe, although considered barely sufficient to help new families, is better than that in Eastern countries. In Asia, fathers are still considered the main breadwinner, and dual income families are desirable but not necessarily encouraged. Hence, there is few to no benefits for new fathers, especially with the cultural norm to put work above families. It is considered normal for fathers to choose work over family occasions, work very long hours every week, and not be involved in parenting (Chandra, 2012). Parental leave and benefits in Asia are lower than Europe and benefit mothers more than fathers.

In Indonesia, new fathers only receive two days of full paid paternity leave compared to three months of full paid maternity leave for mothers. Hong Kong's regulation about the leave is even lower with only three days of $80 \%$ paternity leave and three months of $80 \%$ parental leave (Parental Leave, 2016). Low parental leave has been associated with poor worklife balance and is thought to negatively impact fathers by increasing the chance of post-natal paternal depression (Giallo, Treyvaud, Cooklin, \& Wade, 2012), leading to lower parenting quality and higher stress (Goodman, Crouter, Lanza, Cox, \& Veernon-Feagans, 2011), as well as lower participation in parenting (Machin, 2015). The discrepancy between what fathers need to become more involved in parenting and the benefits provided by the government and workplace are related to a more traditional role of parenting in which mothers are the main caregivers (McLaughlin, Muldoon, \& Moutray, 2010). The better benefits that mothers received are also one of the factors that keep the traditional parenting role in place.

\section{Marital Satisfaction}

With the traditional role still in play for parenting, research shows that one of the best predictors of parenting is marital satisfaction between parents (Friedrich, Wilturner, \& Cohen, 1985). Father involvement has been hypothesised to be directly related to the father and mother's relationship, whether they are married or not, including the couple's relationship quality, couple satisfaction, and co-parenting (Bouchard \& Lee, 2000; Flouri, 2005; Lewis \& Lamb, 2007). When fathers are satisfied with the relationship with mothers, they tend to have a higher quantity and qu- 
ality of involvement in parenting to show their love to their partner (Bouchard \& Lee, 2000; Lee \& Doherty, 2007; Rumaya \& Lim, 2009). Moreover, if mothers perceive fathers to be competent in parenting, fathers tend to be more involved in child-rearing activities (Caldera \& Lindsey, 2006; Galovan, Holmes, Schramm, \& Lee, 2014). Albeit the positive correlation between parental involvement and couple satisfaction, there are several studies that prove otherwise. When the marital satisfaction is high in fathers, the less involved they are in childcare (GothOwens, Stollak, Messe, Peshkess, \& Watts, 1982; Nangle, Kelley, Fals-Stewart, \& Levant, 2003). Additionally, even though many research studies show a positive relationship between fathers' involvement and couple satisfaction, the precise role of this has not been clearly understood, especially with many other aspects included in the explanation, such as motivation to please the partner instead of intrinsic motive (Volling \& Belsky, 1991 as cited in Bouchard $\&$ Lee, 2008). An empirical research study from Bragiel and Kaniok (2011) shows that there is only a slight connection between father involvement and marital satisfaction. The discrepancy of the results implies the need for further research in this area. Furthermore, there is a lack of consideration about culture in past and present studies. Most of the research has only been done in Western society and Chinese culture (Chen, 2012; Lin, 2008; Lin \& Lin, 2009). This increases the need for a broader understanding of the relationship between both factors in other cultures.

\section{Implication for Current Study}

A better understanding of father involvement in parenting is a very important field of research, as the positive effect on both children and fathers has been shown in many research studies as presented above. The previous studies also stated the importance of balancing the working and personal life and need for a good relationship between parents. However, there are only a few studies that investigate the relationship between work-life balance and marital satisfaction with father involvement. Thus, further research and more information is needed to understand the correlation between the three factors.

Correspondingly, previous researchers have seldom incorporated cultural diversity in their studies. In Asian culture itself, there are many different ethnicities, beliefs, and practises. In Indonesia alone, there are 300 ethnicities with different parenting cul- tures that can provide a comprehensive view of a father's involvement in the country. Moreover, Hong Kong is considered a unique country with a blend of Eastern and Western culture because it was a British Colony Chinese country. Due to the uniqueness of these three countries, in this study, the United Kingdom, Hong Kong, and Indonesia have been chosen to provide a broader understanding about father involvement within Asian culture is when compared to Western culture.

This study will examine three research questions: Will United Kingdom fathers show a higher level of involvement in parenting than Asian fathers? Is there any difference in father involvement within Asian cultures (Indonesia and Hong Kong)? Which factor contributes more to father involvement; a father's perception of the couple's satisfaction or the worklife balance?

The hypotheses for the questions are as follows:

1. The United Kingdom fathers show a higher level of involvement in parenting than Asian fathers.

2. There is no significant difference of father involvement within Asian cultures.

3. Father's perception of the couple satisfaction contributes more to the father involvement.

\section{Method}

\section{Participants}

A total of 256 participants from three countries participated in the survey with 51 fathers from the United Kingdom, 106 from Indonesia, and 99 from Hong Kong.

The participants in this research study were mostly within the age range of 30 to $49(n=185,72.3 \%)$. The majority of the sample was married $(n=241$, $94.1 \%)$. The ethnicity was predominantly Asian ( $n$ $=214,83.6 \%$ ) with more than half of the sample had a higher level of education (undergraduate and postgraduate; $n=181,70.8 \%$ ). The children's age was mainly between one and three years of age $(n=$ $75,29.3 \%$ ) and the children's gender amount was almost equal with 129 (50.4\%) girls and 127 (49.6\%) boys.

\section{Procedures}

Recruitment for this cross-cultural study was done simultaneously in the United Kingdom, Hong Kong, and Indonesia through Bristol Online Survey. The 
inclusion criteria for this study are: (a) fathers with children aged 0-18 years old; (b) having an active relationship with the child's biological mother; and (c) currently living in the United Kingdom, Hong Kong, or Indonesia.

Due to language differences in each country, the questionnaires were provided in the following languages: English for the United Kingdom participants, Bahasa for Indonesian participants, and Chinese and English for Hong Kong participants. The recruitment process was done with snowball sampling through social media support groups for fathers (Facebook, Instagram, and Website) and mailing lists of nonprofit organisations for all countries. This study was reviewed and approved by the University of Edinburgh Ethics Committee.

\section{Measures}

Demographic information. Table 1 consists of father ages, marital statuses, education, occupations, and ethnic groups, and children's ages and genders.

Father involvement. The Inventory of Father Involvement is a 26-question questionnaire by Hawkins, Bradford, Palkovitz, and Day (2002) (Appendix C, $\mathrm{D}$, and $\mathrm{E})$. It measures nine dimensions of father involvement including traditional parenting tasks (providing, support for the mother, disciplining and teaching responsibility, encouraging success in school) and additional contemporary parenting tasks (giving praise and affection, spending time together and talking, being attentive to their children's daily lives, reading to their children, and encouraging children to develop their talents) over the past 12 months. The response choices are presented in the form of a Likert scale from 0 for "Very Poor" to 6 "Excellent" and "NA". This inventory has a good range of internally consistent reliability for each dimension $(\alpha=.69-$ .87 ). The face and construct validity were measured with satisfactory results. In this research, the Cronbach's alpha of the Inventory of Father Involvement was .835.

The Indonesian version of the Inventory of Father Involvement was translated by the researcher. To ensure the face validity of the measure, a professional translator back-translated it into English. The result has been found to be suitable with the original version by Hawkins et al. (2002). The reliability of the Indonesian translated version was considered high with a Cronbach's alpha of .923.

The Chinese version of the Inventory of Father Involvement was translated by Yin, Ling, Yang, and
Su (2012). The internal consistency was very high (.95). The test-retest reliability for this measure was high, with a range of .70 to .82 . In this research, the reliability was excellent with a Cronbach's alpha of .948.

Work-life balance. The Work-life Balance questionnaire by Hayman (2005) consists of 15 items adapted from an instrument by Fisher-McAuley et al. (2003) (Appendix C, D, and E). It assesses three dimensions of work-life balance, work interference with personal life (WIPL), personal life interference with work (PLIW), and work/personal life enhancement (WPLE) in the last three months. It uses a seven-point time-related scale ranging from 1 for "Not At All", 4 for "Sometimes", and 7 for "All The Time". The higher the score, the more they experience disturbance, which resulted in a lower work-life balance. Item six is a reverse score. The reliability score for the Work-Life Balance questionnaire is acceptable with a Cronbach's alpha of .93 for WIPL, .85 for PLIW, and .69 for WPLE. The reliability score for this instrument in this research is considerably low with a Cronbach's alpha of .568.

The Indonesian version of the Work-Life Balance questionnaire was translated by Gaby Parung (researcher) and the Chinese version was translated by Vienna Chan (research collaborator). Both versions of the questionnaires were back-translated by a professional translator to ensure face validity for all items. The Cronbach's alpha for the Indonesian and Chinese version were .764 and .818 , respectively.

Couple's satisfaction. The Couple Satisfaction Index (CSI4; shortened version) is a self-report measure that consisted of four questions by Funk and Rogge (2007). It assesses the relationship satisfaction and global evaluation of marital quality. Each item has its own rating scale (Appendix C, D, and E) which ranges from 0 for "Extremely Unhappy" to 6 for "Perfect" or 0 for "Not at All" to 5 for "Completely". The higher the rating, the happier or more satisfactory the marriage. The reliability score for the Couple Satisfaction Index is high (.94). Similarly, the Cronbach's alpha in this research study was also found to be excellent with a score of .927 .

The Indonesian version for the Couple Satisfaction Index was translated by Gaby Parung (researcher) and the Chinese version was translated by Vienna Chan (research collaborator). Both versions of the questionnaires were back-translated by a professional translator to ensure face validity for all items. Both Indonesian and Chinese measurements had high reliability with a Cronbach's alpha of .852 and .910, correspondingly. 
Table 1

Demographic Characteristic of Participants

\begin{tabular}{|c|c|c|c|c|}
\hline \multirow{2}{*}{ Variables } & \multicolumn{4}{|c|}{$N(\%)$} \\
\hline & United Kingdom & Indonesia & Hong Kong & Total \\
\hline \multicolumn{5}{|l|}{ Age } \\
\hline Under 30 & $3(5.9)$ & $14(13.2)$ & $9(9.1)$ & $26(10.2)$ \\
\hline $30-39$ & $27(52.9)$ & $45(42.5)$ & $28(28.3)$ & $100(39.1)$ \\
\hline $40-49$ & $13(25.5)$ & $34(32.1)$ & $38(38.4)$ & $85(33.2)$ \\
\hline Over 49 & $8(15.7)$ & $13(12.3)$ & $24(24.2)$ & 45 (17.6) \\
\hline \multicolumn{5}{|l|}{ Marital Status } \\
\hline Married & $48(94.1)$ & $102(96.2)$ & $91(91.9)$ & $241(94.1)$ \\
\hline Divorced & $1(2)$ & $2(1.9)$ & $5(5.1)$ & $8(3.1)$ \\
\hline Other & $2(4)$ & $2(1.8)$ & $3(3)$ & $7(2.8)$ \\
\hline \multicolumn{5}{|l|}{ Education } \\
\hline Middle School & - & $1(.9)$ & $6(6.1)$ & $7(2.7)$ \\
\hline A-level & $6(11.8)$ & $7(6.6)$ & $30(30.3)$ & $43(16.8)$ \\
\hline Diploma & $4(7.8)$ & $9(8.5)$ & $12(12.1)$ & $25(9.8)$ \\
\hline Undergraduate & $17(33.3)$ & $57(53.8)$ & $27(27.3)$ & $101(39.5)$ \\
\hline Postgraduate & $24(47.1)$ & $32(30.2)$ & $24(24.2)$ & $80(31.3)$ \\
\hline \multicolumn{5}{|l|}{ Occupation } \\
\hline Professional & $27(52.9)$ & $26(24.5)$ & $26(26.3)$ & 79 (30.9) \\
\hline Managers & $5(9.8)$ & $14(13.2)$ & $23(23.2)$ & $42(16.4)$ \\
\hline Businessman & $2(3.9)$ & $25(23.6)$ & $6(6.1)$ & $33(12.9)$ \\
\hline Civil Service & $5(9.8)$ & $21(19.8)$ & $6(6.1)$ & $32(12.5)$ \\
\hline Technicians & $2(3.9)$ & - & $14(14.1)$ & $16(6.3)$ \\
\hline Service and Sales & $2(3.9)$ & $4(3.8)$ & $8(8.1)$ & $14(5.5)$ \\
\hline Clerical & - & $2(1.9)$ & $6(6.1)$ & $8(3.1)$ \\
\hline Students & $5(9.8)$ & - & $1(1)$ & $6(2.3)$ \\
\hline Armed Force & - & $3(2.8)$ & $2(2)$ & $5(2)$ \\
\hline Other & $3(5.9)$ & $11(10.4)$ & $7(7.1)$ & $21(8.2)$ \\
\hline \multicolumn{5}{|l|}{ Ethnicity } \\
\hline Asian & $18(35.3)$ & $102(96.2)$ & $94(94.9)$ & $214(83.6)$ \\
\hline White & $33(64.7)$ & $3(2.8)$ & $4(4)$ & $40(15.6)$ \\
\hline Black & - & $1(.9)$ & $1(1)$ & $2(0.8)$ \\
\hline \multicolumn{5}{|l|}{ Child's Age } \\
\hline $0-12$ months & $8(15.7)$ & $22(20.8)$ & $18(18.2)$ & 48 (18.7) \\
\hline $1-3$ years & $18(35.3)$ & $31(29.2)$ & $26(26.3)$ & 75 (29.3) \\
\hline 4 - 6 years & $9(17.6)$ & $16(15.1)$ & $14(14.1)$ & $39(15.3)$ \\
\hline 7 - 11 years & $7(13.8)$ & $15(14.1)$ & $13(13.1)$ & 35 (13.7) \\
\hline $12-18$ years & $9(17.6)$ & $22(20.8)$ & $28(28.3)$ & $59(23)$ \\
\hline \multicolumn{5}{|l|}{ Child's Gender } \\
\hline Male & $19(37.3)$ & $56(52.8)$ & $52(52.5)$ & $127(49.6)$ \\
\hline Female & $32(62.7)$ & $50(47.2)$ & $47(47.5)$ & $129(50.4)$ \\
\hline
\end{tabular}

Analysis plan. All data analysis was conducted in SPSS 22. First, descriptive analysis was done to describe the demographic information. There was no missing dataset. Second, an independent sample $t$-test was conducted to determine the difference in the father involvement level between United Kingdom and Asian fathers, as well as Indonesian and Hong Kong fathers. Furthermore, the correlation between father involvement, work-life balance, and couple satisfaction was calculated using bivariate correlation tests. When significant correlations between variables were found, a step-wise regression analysis was also conducted.

To perform the step-wise analysis, some variables needed to be changed in the process. Nationality was dummy coded to (a) the United Kingdom as "1" and Indonesia and Hong Kong as "0" and (b) Hong Kong as " 1 " and the United Kingdom and Indonesia as " 0 ". Marital status was decoded to binary with " 1 " for in a relationship and " 0 " for not in a relationship. Occupation was decoded to employed as " 1 " and unemployed as "0". Moreover, father's age was de- 
coded from " 0 " to " 3 " and child's age from " 0 " to " 4 " depending on the age grouping used. Demographic information was chosen as the first step. Nationality was put in the second step and the third step consisted of the measurements of work-life balance and couple satisfaction.

Moreover, an analysis of variance test was implemented to see the difference between groups in the measurements. However, due to the violated assumption in Levene's homogeneity test and the Posthoc result showing a "not significant" result for one measurement, the researcher stated the ANOVA result. The final analysis was done with a Macro developed by Hayes (2016) to look into the possibility of a mediating factor that influences father involvement. The variables used were the work-life balance as an independent factor, father involvement as a dependent factor, and couple satisfaction as a mediating factor.

\section{Results}

There were 256 participants who contributed to this study, with 51 fathers from the United Kingdom, 99 from Hong Kong, and 106 from Indonesia. The majority of the correspondence are new fathers within the range of age 30-39 (39.1\%) and are married with the mother of the child $(94.1 \%)$. Most of the fathers $(70.8 \%)$ are university graduate and higher, and working in a professional occupation (30.9\%). Sixty-three percent of the children are below six years old with nearly balanced ratio of child's gender.

\section{Father Involvement in the United Kingdom and Asian Fathers}

The $t$-test analysis was completed to analyse the mean difference in father involvement between United Kingdom and Asian fathers. The total mean for the fathers from United Kingdom was 112.882 (SD $=17.973$ ). Meanwhile, the mean for Asian fathers was $114.463(S D=29.322)$. The result showed no statistically significant difference between both $(t=-$ $.487, p=.627,95 \%=-8.003,-4.841)$. Fathers from both cultures showed medium average scores in the paternal involvement (UK $M=4.342$, Asian $M=$ 4.402).

The descriptive statistic for the United Kingdom and Asian fathers is presented in Table 2. Both the United Kingdom and Asian fathers had the highest involvement in providing financial support for their children (UK $M=5.411, S D=1.028$; Asian $M=5.112$, $S D=1.205)$ and the second highest in giving affection and praising their children (UK $M=5.196, S D=$ .890; Asian $M=4.946, S D=1.324)$. The similarity can also be found in their very low involvement in encouraging their children in school, such as to succeed in school, do homework, and follow rules at school (UK $M=3.386, S D=2.010$; Asian $M=3.886$, $S D=1.863)$. The second lowest involvement in both countries was different with lower discipline in the United Kingdom fathers $(M=3.771, S D=.852)$ and lower support in reading and doing homework in Asian fathers $(M=3.920, S D=1.526)$.

\section{Father Involvement in Indonesian and Hong Kong Fathers}

The $t$-test analysis showed a statistically significant difference in father involvement between Indonesian and Hong Kong fathers $(t=6.307, p<.000$, $95 \%=16.286,31.101)$. The total mean for Indonesian fathers was $125.906(S D=24.830)$ with an average medium to a high score $(M=4.843)$. Meanwhile, the Hong Kong fathers' father involvement mean was $102.212(S D=28.912)$ with a medium average score $(M=3.931)$.

The descriptive statistic of father involvement subscales is presented in Table 3. Although there is a statistically significant difference in the level of involvement, fathers in both countries had the highest involvement in providing for their children financeally (INA $M=5.524, S D=1.079$; HK $M=4.672$, $S D=1.183$ ). Both also has high involvement in terms of giving praise and affection to their children (INA $M=5.242, S D=1.319$; HK $M=4.630, S D=1.261$ ). Both Asian countries' fathers were low in encouraging their children to do well in school (INA $M=$ 4.267, $S D=1.899$; HK $M=3.478, S D=1.742$ ). Nonetheless, both countries were different in terms of the lowest involvement. Indonesian fathers had low involvement with helping their children do homework or reading to them $(M=4.225, S D=1.422)$ and Hong Kong fathers in disciplining and setting limits $(M=3.434, S D=1.365)$.

\section{Couple Satisfaction and Work-Life Balance Contribution to Father Involvement}

Correlational analysis found that couple satisfaction is the only factor significantly associated to father involvement. There is a positive correlation between couple satisfaction and father involvement 
Table 2

Mean Differences Between the United Kingdom Fathers and Asian Fathers

\begin{tabular}{lcr}
\hline \multirow{2}{*}{ Subscales } & & Mean $(\mathbf{S D})$ \\
\cline { 2 - 3 } & United Kingdom & Asian \\
\hline Discipline and teaching responsibility & $3.771(.852)$ & $4.089(1.430)$ \\
School encouragement & $3.386(2.010)$ & $3.886(1.863)$ \\
Mother support & $4.719(.885)$ & $4.717(1.315)$ \\
Providing & $5.441(1.028)$ & $5.112(1.205)$ \\
Time and talking together & $4.634(.998)$ & $4.585(1.387)$ \\
Praise and affection & $5.196(.890)$ & $4.946(1.324)$ \\
Developing talents and future concerns & $3.987(1.325)$ & $4.400(1.574)$ \\
Reading and homework support & $3.863(1.310)$ & $3.920(1.526)$ \\
Attentiveness & $4.444(1.214)$ & $4.202(1.463)$ \\
Total & 4.342 & 4.402 \\
\hline
\end{tabular}

Table 3

Mean Differences Between Indonesian Fathers and Hong Kong Fathers

\begin{tabular}{lrr}
\hline \multirow{2}{*}{ Subscales } & & Mean (SD) \\
\cline { 2 - 3 } & Indonesian & Hong Kong \\
\hline Discipline and teaching responsibility & $4.701(1.206)$ & $3.434(1.365)$ \\
School encouragement & $4.267(1.899)$ & $3.478(1.742)$ \\
Mother support & $5.186(1.114)$ & $4.216(1.334)$ \\
Providing & $5.524(1.079)$ & $4.672(1.183)$ \\
Time and talking together & $4.918(1.207)$ & $4.229(1.481)$ \\
Praise and affection & $5.242(1.319)$ & $4.630(1.261)$ \\
Developing talents and future concerns & $4.987(1.402)$ & $3.771(1.510)$ \\
Reading and homework support & $4.255(1.422)$ & $3.562(1.559)$ \\
Attentiveness & $4.730(1.277)$ & $3.636(1.444)$ \\
Total & 4.843 & 3.931 \\
\hline
\end{tabular}

with $5.8 \%$ of the total variation determined by the linear relationship between both $(r=.242, n=256$, $p<.000)$. Meanwhile, albeit a good significance level, work-life balance has a very small effect on father involvement, determining only $1.8 \%$ of the variation $(r=-.135, n=256, p=.031)$.

As a result of the regression analysis, it was found that only couple satisfaction significantly contributed to father involvement $(p<.000,95 \%=$ $.703,2.357)$ and work-life balance had not contributed in the involvement $(p=.124,95 \%=-.573$, .069).

Furthermore, with a stepwise regression analysis, it was found that child's age, education level, nationality, work-life balance, and couple satisfaction were statistically significant to determine father involvement. In looking more closely at the stepwise, initially, child's age $(p=.002)$ and father's education level $(p=.015)$ significantly estimated $5.4 \%$ father involvement $\left(R^{2}=.054\right)$. However, in the second step when nationality was added, father's education lost its statistical significance $\left(p=.632, R^{2}=.192\right)$. In the third step of regression, wherein work-life ba- lance and couple satisfaction measurements were added, both education $(p=.631)$ and work-life balance $(p=.221)$ failed to significantly predict father involvement. Children's age $(p=.002)$, nationality $(p<.000, .002)$, and couple satisfaction (.006) were the three significant predictors for father involvement. The data was checked for homogeneity. However, Levene's test for equality of variance was found to be violated in the present analysis (FI $p=$ .007 ; CS $p=.005$; WLB $p=.015$ ). Due to the violated assumption, a Brown-Forsythe's test was done because it is more conservative and fit to the unequal sample size for each country. However, due to the lack of significance for work-life balance, the result from ANOVA was reported with father involvement $(p<.000, F=22.408, S E=0.150)$, couple satisfaction $(p<.000, F=10.262, S E=0.075)$, and work-life balance ( $p=.213, F=1.368, S E=0.011$ ). The data regarding the regression coefficient is provided in Table 4.

A mediation analysis was used to investigate the possible mediation between father involvement, couple satisfaction, and work-life balance owing to the 
Table 4

Regression Coefficient

\begin{tabular}{|c|c|c|c|c|c|c|c|c|c|c|}
\hline \multirow{2}{*}{ Variable } & \multirow{2}{*}{$\beta$} & \multirow{2}{*}{$t$} & \multirow{2}{*}{ Sig. } & \multirow{2}{*}{$\boldsymbol{R}$} & \multirow{2}{*}{$R^{2}$} & \multirow{2}{*}{$\Delta R^{2}$} & \multicolumn{2}{|c|}{$\begin{array}{l}95 \% \text { Confidence } \\
\text { Interval }\end{array}$} & \multicolumn{2}{|c|}{$\begin{array}{c}\text { Collinearity } \\
\text { Statistics }\end{array}$} \\
\hline & & & & & & & $\begin{array}{l}\text { Lower } \\
\text { Bound }\end{array}$ & $\begin{array}{l}\text { Upper } \\
\text { Bound }\end{array}$ & Tolerance & VIF \\
\hline $\begin{array}{l}\text { Step 1 } \\
\quad \text { Child's age }\end{array}$ & .176 & 2.857 & .005 & .176 & .031 & .027 & 1.036 & 5.633 & 1.000 & 1.000 \\
\hline Step 2 & & & & .232 & .054 & .046 & & & & \\
\hline $\begin{array}{l}\text { Child's age } \\
\text { Father's education }\end{array}$ & $\begin{array}{l}.189 \\
.151\end{array}$ & $\begin{array}{l}3.083 \\
2.454\end{array}$ & $\begin{array}{l}.002 \\
.015\end{array}$ & & & & $\begin{array}{l}1.291 \\
1.788\end{array}$ & $\begin{array}{c}5.859 \\
16.322\end{array}$ & $\begin{array}{l}.993 \\
.993\end{array}$ & $\begin{array}{l}1.007 \\
1.007\end{array}$ \\
\hline $\begin{array}{l}\text { Step } 3 \\
\text { Child's age } \\
\text { Father's education } \\
\text { Nationality - UK } \\
\text { Nationality - HK } \\
\end{array}$ & $\begin{array}{l}.205 \\
.029 \\
-.188 \\
-.427 \\
\end{array}$ & $\begin{array}{c}3.597 \\
.480 \\
-3.038 \\
-6.540\end{array}$ & $\begin{array}{l}.000 \\
.632 \\
.003 \\
.000 \\
\end{array}$ & .439 & .192 & .179 & $\begin{array}{c}1.753 \\
-5.404 \\
-21.201 \\
-31.211 \\
\end{array}$ & $\begin{array}{c}5.996 \\
8.886 \\
-4.523 \\
-16.763 \\
\end{array}$ & $\begin{array}{l}.990 \\
.884 \\
.842 \\
.755 \\
\end{array}$ & $\begin{array}{l}1.010 \\
1.132 \\
1.187 \\
1.325 \\
\end{array}$ \\
\hline Step 4 & & & & .475 & .226 & .207 & & & & \\
\hline Child's age & .213 & 3.800 & .000 & & & & 1.942 & 6.122 & .986 & 1.014 \\
\hline Father's education & .029 & .481 & .631 & & & & -5.374 & 8.850 & .862 & 1.161 \\
\hline Nationality - UK & -.187 & -3.062 & .002 & & & & -21.034 & -4.569 & .835 & 1.198 \\
\hline Nationality - HK & -.378 & -5.729 & .000 & & & & -28.504 & -13.919 & .716 & 1.397 \\
\hline Couple satisfaction & .165 & 2.783 & .006 & & & & .328 & 1.914 & .888 & 1.126 \\
\hline Work-life balance & -.071 & -1.226 & .221 & & & & -.486 & .113 & .939 & 1.064 \\
\hline
\end{tabular}

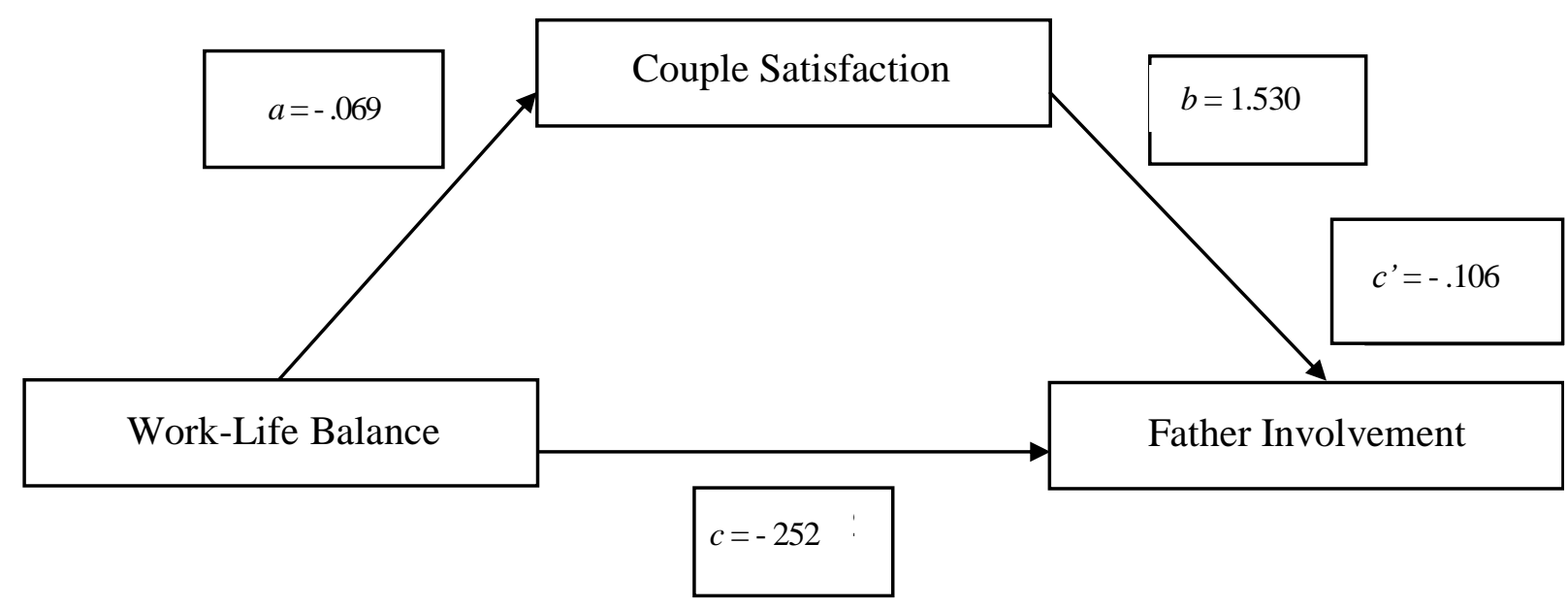

Figure 1. Mediation analysis.

correlation between the three measurements. The result indicated that work-life balance had no significant direct relationship with father involvement $(c$ $=-.252, S E=.163, p=.124, C I=-.573, .069)$. In the indirect relationship between both factors with couple satisfaction as a mediator, the analysis showed that work-life balance was a significant predictor of couple satisfaction, $a=-.069, S E=-.024, p=$ $.004, C I=-.116,-.022$ and that couple satisfaction was a significant predictor of father involvement, $b$ $=1.530, S E=.420, p<.000, C I=.703,2.358$. The result also indicated that the indirect coefficient was significant, $c^{\prime}=-.106, S E=.66, C I=-.283,-.018$. These results are shown in Figure 1.

\section{Discussion}

The aim of the present study was, first, to indicate the difference in father involvement level in the United Kingdom and Asian fathers. Second, it aimed to see the difference of father involvement within 
Asian countries, specifically Indonesia and Hong Kong. Finally, the present research aimed to investigate which factor contributes more to father involvement, work-life balance or couple satisfaction.

Firstly, the researcher indicates the difference of father involvement in the United Kingdom and Asian fathers. The recognition of father involvement has been growing in Western society, especially for new fathers. Being involved in parenting has been considered to be a normative norm for fathers in the United Kingdom (Dermott, 2008). With the different definition of good fatherhood in the Western and Eastern countries, it had been previously predicted that fathers in the United Kingdom will have a higher level of involvement in the parenting practice. However, no significant difference in father involvement between the United Kingdom and Asian fathers was found in this study. The similarity between countries can be found in the two most important factors that influenced the father involvement, providing for children financially and giving praise and affection to them. The first factor was aligned to the traditional parenting wherein a father's main task was to be the breadwinner for their family. Although the trend has been changing and women have also stated to work and build their own careers, men were still expected to be the primary source of income (Elia, 2000; Lamb, 2000).

The similarity in praising their children between these two countries is intriguing. Due to the fact that Western fathers were expected to be more caring and practice authoritative parenting, it was expected that their praising and giving of affection would be one of the most important factors that influenced their level of involvement. They were more used to praising their children verbally (Moss \& Deven, 1999; McLaughlin \& Muldoon, 2014). However, fathers in the East were culturally stricter and disciplinarian (Siraj, 2007). This recent finding, which showed that fathers in Asia valued praise and affection as the second most important factor, was worth mentioning. The change might be owed to new Asian fathers who were not following their culture's tradition of tough parenting and pivoting their parenting practises to the Western fathers' style which eventually even up their level of involvement (Kwok \& Li, 2014). This contradiction with previous research was also found in school encouragement factor. Education was considered to be one of the most important factors in Asia. With high competition for a good job, parents had been preparing their children to attend the best school since primary school and this continued until their children reached university or even found prestigious jobs. However, this factor was found to be the least important factor in Asian fathers in this research. The reason for it being less important for fathers was because education was still the responsibility of mothers in Asia (Philipson \& Philipson, 2010).

Another reason for the higher level of father involvement in Asian fathers was the working mother trend in Asia. Being a working mother was considered a normal thing in the United Kingdom. However, the movement just started in Asia within the last decade. Even now, women are still not encouraged to work outside the house. With mothers unavailable to take care of children all the time, the responsibility for child bearing must be shared with fathers (Chen, 2013). This might have encouraged the involvement of fathers. Other than that, the awareness of father involvement has also been increasing significantly in Asia. There are many social support networks on social media. Parenting blog such as Ayah Edy and Ayah ASI in Indonesia and Dads in Hong Kong and HK Dads in Hong Kong helped fathers acquire information about parenting. They can also share their questions and problems on the platform and other fathers can help answer their questions. These platforms help fathers increase their confidence and involvement in parenting (Lamb, Pleck, \& Levine, 2010).

Previous research highlighted the culture of individualism and collectivism as the cause of different levels of father involvement in Western and Eastern countries. In individualistic countries, new parents might not be able to ask for help from their extended families; hence, new fathers need to help their spouses to take care of their babies. In contrast, families in the East were all involved in parenting and fathers might not feel the urgency to help (Hossain et al., 2005; Suppal \& Roopnarine, 1999). Yet, according to Hofstede (2016), the United Kingdom scored 89 in the degree of individualism while Indonesia and Hong Kong only scored 14 and 25, respectively. This might imply that there was no correlation between individualism/collectivism and father involvement. However, more in-depth research must be done to prove the relationship between both.

Secondly, the researcher indicates the difference of father involvement within Asian countries. Intriguingly, a significant difference in father involvement was found between Indonesian and Hong Kong fathers. Fathers in both countries value involvement factors and rank it in a similar way; however, Indonesian fathers consistently lead the degree of involvement in all aspects with an overall significant gap 
(Table 2). The first aspect was providing for the children in financial matters. This was supported by previous research that explained that fathers were traditionally expected to be the breadwinners for the families (Lamb, 2000). Moreover, in Asia, that role is considered to be the utmost role of fathers, even when they are starting to be more involved in parenting (Chandra, 2012). The higher the wage, the more successful they are as fathers. With this mindset, fathers were having little time with the family. Nonetheless, in this research study the level of involvement was medium.

In this research study, Hong Kong fathers considered disciplining their children and encouraging their children in school to be the two lowest aspects in involvement in child rearing. This result stood in contradiction to the phenomenon that occurs in Hong Kong nowadays, that of the helicopter parents. Helicopter parents are parents who are overprotective and excessively involved in their children's lives by making every decision in their lives and pushing the limits exceeding the boundaries of children's academic capabilities to ensure their children's success in the future. They also had a mindset in that, if their children fail from the beginning, they will fail in every step in the future. Hence, toddlers in Hong Kong were prepared to study and enrol in the best nurseries. High competition to enter the best schools may also put pressure on both the children and parents (Fingerman, Cheng, Wesselmann, Zarit, Furstenberg, $\&$ Birditt, 2012). With the lower involvement of fathers in disciplining and encouraging children in school, it might be safe to conclude that the ones who perform this act the most are often the mothers. The parenting practises in Hong Kong might still follow traditional parenting conventions, even with higher involvement of fathers (Juhari, Yaacob, \& Talib, 2013).

The difference in father involvement between Indonesian and Hong Kong fathers might be due to the cultures and traditions in each country. Culture is a set of patterns of beliefs and behaviours that are shared by a group of people that control their daily living habits, including parenting (Bornstein, 2012). Guidelines and values of parenting are conceptualised and transmitted within culture and structure the way parents raise their children (Riani, Meredith, \& Cuskelly, 2016). Subsequently, different cultures may shape different ways of father involvement.

Different values that are present, even within Asian cultures, might influence the difference of father involvement. Among the more than 300 ethnicities in
Indonesia, they are all value children very highly within the nuclear and extended families. Even before the child has been born, there are often already a lot of cultural ceremonies for the safe delivery and health of the baby. For example, within Javanese and Sundanese (the largest ethnicities in Indonesia) cultures, the ceremonies start from the prenatal term in the fourth and seventh months, to the post-natal on the first day, first month, and the following months, depending on the culture (Riani, Meredith, \& Cuskelly, 2016). Fathers are expected to be involved in these rituals; hence, the bonding process between father and child starts very early and formally.

As a nation, Hong Kong recognises Chinese religions such as Confucianism and Taoism in their culture. However, their citizens view the religious practice as cultural and no longer as a part of worship or religion (Religion in Hong Kong, 2016). Compared to Hong Kong, Indonesian citizens put high importance on religion in everyday life. The nation's ideology, Pancasila, also includes religious notions, with the first article stating "believe in the one and only God" (Litaay, 2012). Hence, it is religion is expected to be included in their lives, including parenting. As the largest Muslim country in the world, most families in Indonesia utilise Islamic values in raising their children (Sari, 2013). In Islam, a man is considered to be the leader of the family and has to support and provide for them. The father should also be able to lead and be kind to the children because they are the source of blessing and happiness (Ismail, 2003; Juhari, Yacoob, \& Talib, 2010). Similarly, children are valued highly in the Christian belief system. There are many families who are Christian that raise their children accordingly in Indonesia (Sari, 2013). It is stated that fathers should love and respect their children; however, fathers also need to discipline them to help them become decent adults later. As the head of the family, fathers should be the ones to teach the children (McRay, 2009).

Finally, the researcher indicates the factor which contributes the most to father involvement. Other than the measurements measured, demographic factors were also found to be contributing factors to father involvement, such as the child's age, nationality, as well as the father's education. Nationality has an impact on father involvement with higher involvement in Indonesian fathers and the lowest involvement in Hong Kong fathers. Also, there was no difference in father involvement between United Kingdom and Asian fathers. Second, in alignment with previous studies, the present research found 
that the child's age has a positive relationship with father involvement. Fathers were more involved with younger children because they need more caring for, time, and attention (Biggard \& O'Brien, 2010; Fisher, McCulloch, \& Gershuny, 1999; Yeung, Sandberg, Davis-Kean, \& Hofferth, 2001). Moreover, with the paternity leave only given in the first year after the children's birth, it became clear that fathers spend more time with younger children. Third, fathers' education had no correlation with father involvement. This finding was in contrast with previous research as fathers' education was hypothesised to be one of the most determining factors in father involvement. The higher the fathers' education, the more involved they are in child rearing activities (Holmes \& Huston, 2010; Nordhal, Zambrana, \& Forgatch, 2015; Yeung, 2010).

Work-life is one of the most important identities in men's lives. With a significant portion of their time used for work, it was inevitable that they would have less time to parent, especially after the paternity leave ends (McLaughlin \& Muldoon, 2014). Moreover, their involvement might be hampered by the stress from work. However, the work-life balance did not demonstrate a correlation to father involvement in the present study. This was in contrast with the research from Warren (2003) which stated that work-life balance was a significant determinant for paternal involvement. One of the reasons for the lack of a correlation in this research study was due to the couple satisfaction with an indirect relationship.

Couple satisfaction was positively correlated to father involvement in this research. The association was consistent with previous findings claiming that fathers with higher satisfaction in the marital relationship were more involved in child rearing activities (Friedrich, Wilturner, \& Cohen, 1985; Bouchard \& Lee, 2000; Flouri, 2005; Lewis \& Lamb, 2007) and disagree with research stating otherwise (Goth-Owens, Stollak, Messe, Peshkess, \& Watts, 1982; Nangle, Kelley, Fals-Stewart, \& Levant, 2003). Due to the fact that new fathers value relationship and commitment highly, fathers may engage more in parenting to please their spouses. Fathers with a high level of satisfaction might also be encouraged by their spouses to learn and be more involved in child rearing (Kwok, Ling, Leung, \& Li, 2012). Other than their direct relationship, couple satisfaction moderated the relationship between work-life balance and father involvement. Even with the lack of balance in fathers' work and private lives, as long as they have a satisfying relationship with their spouses, they will still be involved in parenting. This acts as a buffer to reduce the negative impact of work stress on their involvement for several reasons. First, couple satisfaction can create a healthy and happy family environment that encourages fathers to be more involved in the family. Second, it also moderates the impact through spouses' support (Kalil et al., 2005) and fathers' motivation to show love and affection to them (Kwok, Ling, Leung, \& Li, 2012).

With the discovery of the importance of couple satisfaction in encouraging father involvement, some practical implications can be derived from the results. First, a new model can be developed to further understand father involvement. Second, with further research that proves the significance of couple satisfaction on father involvement, family therapists can use the model to increase father involvement in child rearing by improving the couples' relationship first. Third, parenting programs that involve parents can also be held to promote healthy and open relationships that may help develop mutual agreement in parenting practises.

\section{Limitations and Direction for Future Research}

The present study has several limitations. First, the reliability of the Work-Life Balance questionnaire was low $(r=.568)$. With low reliability in all items for WPLE factor, it might be concluded that WPLE might not measure the work-life balance accurately. Hence, the result about work-life balance must be taken with caution. Further research may need to perform factorial analysis to understand the measurement better. Different measurements can also be used to test the relationship between work-life balance and father involvement. Second, the data for father involvement was solely from the fathers' perspectives and might not accurately depict their involvement in parenting. Moreover, the data was collected with a self-reporting measure that is high in bias. For future research, the cross-examining of data with mothers' perceptions of father involvement might need to be conducted to obtain a more objective understanding. Third, with the finding of significant differences in father involvement within Asian culture, a cross-cultural study with a smaller scope utilising factors such as ethnicity might be needed. Finally, there was no open question in this research; hence, there was no in depth data obtained. Future studies can incorporate open questions or integrate the qualitative method to acquire more thorough and in-depth analysis regarding father involvement. 


\section{Conclusion}

In summary, this research aimed to investigate the father involvement level of the United Kingdom fathers compared to Asian fathers, and also its level within Asian fathers. It also aimed to investigate the most influencing factor to father involvement. Father involvement level is varied according to the country but generally new fathers in all three countries are focusing their involvement by providing financial support for family and also putting importance in active relationship with their children. Despite the limited number of research which connect both marital satisfaction and work-life balance to father involvement, this exploratory research shows positive and promising result to increase fathers' participation in child rearing activities. This study confirms that healthy and satisfying relationship could not only accommodate higher father involvement but also reduce the stress which comes from the imbalance work and personal life.

\section{References}

Aldous, J., \& Mulligan, G. M. (2002). Fathers' child care and children's behavior problems: A longitudinal study. Journal of Family Issues, 23(5), 624647.

Aumann, K., Galinsky, E., \& Matos, K. (2011). The new male mystique: Families and work institute national study of the changing workforce. Retrieved from http://www.familiesandwork.org/site/re search/reports/main.html

Baruch, G. K., \& Barnett, R. C. (1986). Consequences of fathers' participation in family work: Parents' role strain and well-being. Journal of Personality and Social Psychology, 51(5), 983-992.

Biggart, L., \& O'Brien, M. (2010). UK fathers' long work hours: Career stage of fatherhood? Fathering, 8(3), 341-361.

Bornstein, M. H. (2012). Cultural approaches to parenting. Parenting, 12, 212-221.

Bouchard, G., \& Lee, C. M. (2000). The marital context for father involvement with their preschool children. Journal of Prevention \& Intervention in the Community, 20, 37-53.

Bragiel, J., \& Kaniok, P. E. (2011). Fathers' marital satisfaction and their involvement with their child with disabilities. European Journal of Special Needs Education, 26(3), 395-404.

Caldera, Y. M., \& Lindsey, E. W. (2006). Coparent- ing, mother-infant interaction, and infant- parent attachment relationships in two-parent families. Journal of Family Psychology, 20(2), 275-283.

Chandra, V. (2012). Work-life balance: Eastern and western perspectives. The International Journal of Human Resource Management, 23(5), 1040-1056.

Chen, H. H. (2012). Couple relationship quality, coparenting, and fathering in Taiwan. Early Child Development and Care, 183(6), 827-842.

Crompton, R., \& Lyonette, C. (2008). Who does the housework? The division of labour within the home. In A. Park, J. Curtice, K. Thomson, M. Phillips, \& M. Johnson (Eds.), British Social Attitudes: The 24th Report. London: Sage.

Dermott, E. (2008). Intimate fatherhood: A sociological analysis. London: Routledge.

Elia, H. (2000). Peran ayah dalam mendidik anak. Veritas, 1(1), 105-113.

Fagnani, J., \& Letablier, M. T. (2004). Work and family life balance: The impact of the 35-hour laws in France. Work, Employment \& Society, 18(3), 551572.

Fingerman, K. L., Cheng, Y. P., Wesselmann, E. D., Zarit, S., Furstenberg, F., \& Birditt, K. S. (2012). Helicopter parents and landing pad kids: Intense parental support of grown children. Journal of Marriage and Family, 74(4), 880-896.

Fisher, K., McCulloch, A., \& Gershuny, J. (1999). British fathers and children. Colchester: University of Essex, Institute for Social and Economic Research.

Fisher-McAuley, G., Stanton, J., Jolton, J. \& Gavin, J. (2003). Modelling the relationship between work-life balance and organisational outcomes. Paper presented at the Annual Conference of the Society for Industrial-Organisational Psychology: Conference Proceeding (pp. 1-26.), April 12, 2003.

Flouri, E. (2005). Fathering and child outcomes. Chicester: John Wiley \& Sons Ltd.

Flouri, E., \& Buchanan, A. (2002). Father involvement in childhood and trouble with the police in adolescence: Findings from the 1958 British cohort. Journal of Interpersonal Violence, 17(6), 689-701.

Friedrich, W. N., Wilturner, L. T., \& Cohen, D. S. (1985). Coping resources and parenting mentally retarded children. American Journal of Mental Deficiency, 90(2), 130-139.

Funk, J. L., \& Rogge, R. D. (2007). Testing the ruler with item response theory: Increasing precision of measurement for relationship satisfaction with the couple satisfaction index. Journal of Family Psy- 
chology, 21(4), 572-583.

Galovan, A. M., Holmes, E. K., Schramm, D. G., \& Lee, T. R. (2014). Father involvement, father-child relationship quality, and satisfaction with family work: Actor and partner influences on marital quality. Journal of Family Issues, 35(13), 1846-1867.

Giallo, R., Treyvaud, K., Cooklin, A., \& Wade, C. (2012). Mothers' and fathers' involvement in home activities with their children: Psychosocial factors and the role of parental self-efficacy. Early Child Development and Care, 183(3-4), 343-359.

Goodman, W. B., Crouter, A. C., Lanza, S. T., Cox, M. J., \& Vernon-Feagans, L. (2011). Paternal work stress and latent profiles of father-infant parenting quality. Journal of Marriage and Family, 73, 588-604.

Goth-Owens, T. L., Stollak, G. E., Messe, L. A., Peshkess, I., \& Watts, P. (1982). Marital satisfaction, parenting satisfaction, and parenting behavior in early infancy. Infant Mental Health Journal, 3, 187-198.

Gray, A. (2006). The time economy of parenting. Sociological Research Online, 11(3). Retrieved from http://www.socresonline.org.uk/11/3/gray. html

Gregory, A., \& Milner, S. (2010). Fathers and worklife balance in France and the UK: Policy and practice. International Journal of Sociology and Social Policy, 31(1-2), 34-52.

Halford, S. (2006). Collapsing the boundaries? Fatherhood, organization and home-working. Gender, Work and Organization, 13, 383-402.

Hawkins, A. J., \& Palkovitz, R. (1999). Beyond ticks and clicks: The need for more diverse and broader conceptualizations and measures of father involvement. The Journal of Men's Studies, 8, 11-32.

Hawkins, A. J., Bradford, K. P., Palkovitz, R., \& Day, R. D. (2002). The inventory of father involvement: A pilot study of a new measure of father involvement. The Journal of Men's Studies, 10(2), 183-196.

Hayes, A. F. (2016). Partial, conditional, and moderated mediation: Quantification, inference, and interpretation. Manuscript in review.

Hayman, J. (2005). Psychometric assessment of an instrument designed to measure work life balance. Research and Practice in Human Resource Management, 13(1), 85-91.

Haywood, C., \& Mac an Ghail, M. (2003). Men and masculinities. Buckingham: Open University Press.

Hofstede, G. (2016). Hofstede Insights: Compare countries. Retrieved from https://www.geert-hofste de.com/countries.html

Holmes, E. K., \& Huston, A. C. (2010). Understanding positive father-child interaction: Childrens', fathers', and mothers' contributions. Fathering: A Journal of Theory, Research, and Practice about Men as Fathers, 8, 203-225.

Hossain, Z., Roopnarine, J. L., Masud, J., Muhamed, A. A., Baharudin, R., Abdullah, R., \& Juhari, R. (2005). Mothers' and father' childcare involvement with young children in rural families in Malaysia. International Journal of Psychology, 40(6), 385394.

Hsu, J. (1985). The Chinese family: Relations, problems, and therapy. In W. S. Tseng \& D. Wu (Eds.), Chinese culture and mental health (pp. 95-111). New York: Academic Press.

Ismail, P. (2003). Kekeluargaan Islam menurut AlQuran dan Al Sunnah. Kuala Lumpur: Penerbit Universiti Malaya.

Janzen, B. L., \& Kelly, I. W. (2012). Psychological distress among employed fathers' associations with family structure, work quality, and the work-family interface. American Journal of Men's Health, 6, 294-302.

Juhari, R., Yaacob, S. N., \& Talib, M. A. (2010). Correlates of father involvement amongst Muslim fathers in Malaysia. International Journal of Social Policy and Society, 7, 90-103.

Juhari, R., Yaacob, S. N., \& Talib, M. A. (2013). Father involvement among Malay Muslims in Malaysia. Journal of Family Issues, 34(2), 210-229.

Kaplan, M. D. (1996). The role of fathers. Journal of the American Academy of Child and Adolescents Psychiatry, 35(6), 699-700.

Keizer, R. (2015). Which men become involved fathers? The impact of men's own attitudes on paternal involvement in Netherlands. International Review of Sociology, 25(3), 359-372.

Kwok, S. Y. C. L. \& Li, B. K. K. (2014). A mediation model of father involvement with preschool children in Hong Kong. Social Indicator Research, 122, 905-923.

Kwok, S. Y. C. L., Ling, C. C. Y., Leung, C. L. K., \& Li, J. C. M. (2013). Fathering self-efficacy, marital satisfaction and father involvement in Hong Kong. Journal of Child and Family Studies, 22, 1051-1060.

Lamb, M. E. (Ed.). (2004). The role of the father in child development (4th ed.). Hoboken, NJ: Wiley.

Lamb, M. E., Pleck, J. H., \& Levine, J. A. (2010). Chapter 6: Effects of paternal involvement on fathers and mothers. Marriage and Family Review, 
9(3-4), 67-83.

Lamb, M. E., Pleck, J. H., Charnov, E. L., \& Levine, J. A. (1987). A biosocial perspective on paternal involvement. In J. Lancaster, J. Altmann, A. Rossi, $\&$ L. Sherrod (Eds.), Parenting across the lifespan: Biosocial dimensions (pp. 111-142). New York: Aldine de Gruyter.

Lamb, M. E. (2000). The history of research on father involvement: An overview. In H. E. Peters, G. W. Peterson, S. K. Steinmetz, and R. D. Day (Eds.), Fatherhood: Research, intervention and policies, pp. 23-40.) New York, London, Oxford: The Haworth Press, Inc.

Lee, C. S., \& Doherty, W. J. (2007). Marital satisfaction and father involvement during the transition to parenthood. Fathering, 5(2), 75-96.

Lewis, C., \& Lamb, M. (2007). Understanding fatherhood: A review of recent research, York: Joseph Rowntree Foundation.

Lin, H. Y. (2008). Associations between parental role identity and coparenting. Research in Applied Psychology, 38, 209-251.

Lin, Y. P., \& Lin, H. Y. (2009). Patterns of coparenting processes. Indigenous Psychological Research in Chinese Societies, 32, 41-97.

Litaay, A. (2012). Pancasila and tolerance in a pluralistic Indonesian society, toward a better common future. Jakarta: Migrant Consortium.

Machin, A. J. (2015). Mind the gap: The expectation and reality of involved fatherhood. Fathering, 13(1), 36-59.

Maternity Pay and Leave. (2016). Retrieved July 10, 2016 from https://www.gov.uk/maternity-pay-lea ve/overview

McLaughlin, K., \& Muldoon, O. (2014). Father identity, involvement and work-family balance: An in-depth interview study. Journal of Community \& Applied Social Psychology, 24, 439-452.

McLaughlin, K., Muldoon, O. T., \& Moutray, M. (2010). Gender, gender roles and completion of nursing education: A longitudinal study. Nurse Education Today, 30(4), 303-307. http://dx.doi.org /10.1016/j.nedt.2009.08.005.

Mehall, K. G., Spinrad, T. L., Eisenberg, N., \& Gaertner, B. M. (2009). Examining the relations of infant temperament and couple's marital satisfaction to mother and father involvement: A longitudinal study. Fathering, 7(1), 23-48.

Moss, P., \& Deven, F. (Eds). (1999). Parental leave: Progress or pitfall? Brussels: NIDI/CBGS Publication.
Nangle, S. M., Kelley, M. L., Fals-Stewart, W., \& Levant, R. F. (2003). Work and family variables as related to paternal engagement, responsibility, and accessibility in dual-earner couples with young children. Fathering: A Journal of Theory, Research and Practice About Men as Fathers, 1(1), 71-90.

Nepomnyaschy, L., \& Waldfogel, J. (2015). Paternity leave and fathers' involvement with their young children. Community, Work \& Family, 10(4), 427453.

Newland, L. A., Chen, H. H., Coyl-Shepherd, D. D., Liang, Y. C., Carr, E. R., Dykstra, E., \& Gapp, S. C. (2012). Parent and child perspectives on mothering and fathering: The influence of ecocultural niches. Early Child Development and Care, 183(34), 534-552.

Newland, L. A., \& Coyl, D. D. (2010). Fathers' role as attachment figures: An interview with $\mathrm{Sir} \mathrm{Ri}-$ chard Bowlby. Early Child Development and Care, 180(1-2), 25-32.

Nordhal, K. B., Zambrana, I. M., \& Forgatch, M. S. (2015). Risk and protective factors related to fathers' positive involvement and negative reinforcement with 1-year-olds. Parenting, 16(1), 1-21.

O'Brien, M. (2005). Shared caring: Bringing fathers into the frame. Working Paper Series No. 18. Manchester: Equal Opportunities Commission.

Parental Leave. (2016). Retrieved from https://en. wikipedia.org/wiki/Parental_leave

Paternity Pay and Leave. (2016). Retrieved from https://www.gov.uk/paternity-pay-leave/overview

Religion in Hong Kong. (2016). Retrieved from https ://en.wikipedia.org/wiki/Religion_in_Hong_Kong

Rumaya, J., \& Lim, J. (2009). Correlates of fathering behaviour amongst Bidayuh males in Sarawak. Paper presented at the Southeast Asia Psychology Conference, Universiti Malaysia, Sabah.

Sari, Y. F. M. (2013). Peranan gereja Batak Karo Protestan dalam melestarikan dan mempertahankan kebudayaan suku Batak Karo (Studi di Kecamatan Medan Selayang) (Unpublished doctoral dissertation). Universitas Sumatera Utara, Medan, Indonesia.

Shared Parental Leave and Pay. (2016). Retrieved from https://www.gov.uk/shared-parental-leaveand-pay/overview

Siraj, H. (2007). Keibubapaan dalam Islam [Parenting in Islam]. In A. Sobian (Ed.), Keluarga Islam, Kemahiran Keibubapaan dan Cabaran Semasa [Islamic family, parenting skill and current chal- 
lenges] (59-80). Petaling Jaya, Malaysia: MPH \& Institut Kefahaman Malaysia.

Suppal, P. G., \& Roopnarine, J. L. (1999). Paternal involvement in child care as a function of maternal employment in nuclear and extended families in India. Sex Roles, 40(9-10), 731-744.

Turcotte, G., Dubeau, D., Bolte', C., \& Paquette, D. (2001). Pourquoi certains pe'res sont-ils plus engage's que d'autres aupre's de leurs enfants? Une revue des de terminants de l'engagement paternel. Revue Canadienne de Psycho-education, 30, 65-91. Voydanoff, P. (2005). Consequences of boundaryspanning demands and resources for work-to-family conflict and perceived stress. Journal of Oc- cupational Health Psychology, 10, 491-503.

Yeung, J. W., Sandberg, J. F., Davis-Kean, P. E., \& Hofferth, S. L. (2001). Children's time with fathers in intact families. Journal of Marriage and $\mathrm{Fa}$ mily, 63, 136-154.

Yeung, W. J. (Ed.). (2010). International conference on fatherhood in 21st Century Asia: Research, interventions and policies. NUS Bukit Timah Campus, June 17-18, 2010. Singapore: Asia Research Institute.

Yin, X., Li, Z., Yang, X., \& Su, L. (2012). Reliability and validity of the Chinese vision of inventory of father involvement. Chinese Mental Health Journal, 26(7), 557-560. 